\title{
Urban Identity: A Proposad Method for Evaluating the Conservation of Historical Urban Environments
}

\author{
Saliha Taşçıoğlu ${ }^{1} \odot$, Berrin Sirel ${ }^{2} \odot$ \\ 1 Assist. Prof. Dr., Kilis 7 Aralık University, Vocational School of Technical Sciences, Department of Park and Horticulture. \\ (Principal contact for editorial correspondence), Email: slhtascioglu@gmail.com \\ 2 Assist. Prof. Dr. Cukurova University, Faculty of Agriculture, Department of Landscape Architecture. Email: \\ bsirel@cu.edu.tr
}

\begin{abstract} Purpose

Identity elements are the main determinants of urban perception and urban image. Evaluated in this sense, it is of great importance to create renewal and renovation works in the historical urban textures, which have had a unique character in the past and have survived to the present day, according to the ecological and socio-economic structure of the region. This study aims to evaluate the conservation and renovation works carried out in the urban protected areas in Gaziantep and Antakya based on the urban identity elements.

\section{Design/Methodology/Approach}

The urban identity elements to be evaluated in the study area were determined, and forms and charts were prepared to create these evaluations. Evaluation results based on 5-point Likert scale were weighted in accordance with expert opinions and conservation index maps were created based on the determined values and interpreted with the help of ArcGIS software. As a result of the quantitative evaluations, identity elements of the conservation activities and their effects on their environment were expressed with the help of maps

\section{Findings}

it has been determined that the value of the historical texture can be preserved by adopting the traditional fabric and faithful conservation works, moreover the additions and material changes have negative effects.

\section{Research Limitations/Implications}

In the study model was carried out in a narrow area, such as the Gaziantep and Antakya urban site area.

\section{Social Implications}

Uniform protection can be prevented by considering historical cities in a way that reflects their identity. Thus, it can be ensured that protection principles are determined according to the concepts of heritage and value and these values are passed on to future generations.

Originality/Value

Considering historical cities serve as cultural bridges, the article is important in terms of examining conservation in these cities.
\end{abstract}

Keywords: Historical environment conservation, Urban Identity, Gaziantep, Antakya 


\section{INTRODUCTION}

Identity is an expression that describes the individuality, uniqueness and authenticity of an object as well as being a feature that creates the status of being recognizable within other objects. Identity elements are the main determinants of urban perception and urban image (Lynch, 1960). Evaluated in this sense, the streets, squares, parks, open spaces, urban spaces, which have a great impact on social life, are expressed as areas where the citizens meet each other, fuse together, and create urban culture (Erdönmez \& Akl, 2005). Therefore, the issue of preserving city identity, which forms the feelings of belonging and commitment in societies, gains more importance while keeping up with the globalizing world (Hergül \& Sayın, 2017). In this sense, it would be wrong to evaluate cities only as a space of physical entity. Like every other entity, cities have a soul and an identity. This is one of the reasons why they have been exposed to socio-economic, ideological and political struggles over the years (Esendemir, 2015). Therefore, it is important to understand the necessity of continuity by considering this aspect of cities. As a result, they will gain continuity with the preservation of historical identity of the cities (Velioglu et al, 1993).

In this sense, many cities in the world have areas where identity and space add meaning through their historical and cultural relations. They are often an integral part of the city's image and culture (Tiesdell et al, 1996). The texture of historical cities depends not only on its physical structure, but also on various behaviours and activities, and offers a unique human identity (Dhingra et al, 2016). In short, historical urban areas are a part of the history and memory of cities, the basic elements of urban landscape and excellent representatives of the urban style. Especially when buildings are considered as a whole, they constitute historical character (Wang, 2011). Historical city centres are a texture formed by streets and buildings from different periods formed by various cultural and urban strata. For centuries they have formed the character of the city and now they show the quality of urban culture. The right urban preservation is to transform historical cities into cultural activity centres rather than into residential areas (Cohen, 1999).

The aim of this study is to determine the correctness of the debates about the loss of identity and culture in cities and their transformation into too similar cities without identity as a result of conservation works. This study aims to evaluate the conservation and renovation works carried out in the urban protected areas in Gaziantep and Antakya based on the urban identity elements and to determine their conservation status. Urban identity elements in the historical urban fabric of Gaziantep and Antakya, which constitute the study area, are examined in two groups as settlement and reinforcement scale. Scoring was made on the charts prepared for the purpose and their protection levels were determined. The values obtained were weighted according to expert opinions, protection index values were calculated and mapped. 
A Proposad Method for Evaluating the Conservation of Historical Urban Environments

\section{METHODOLOGY}

\section{Research case}

Antakya: The ancient city of Antakya was founded between the Asi River and the Habib-i Neccar Mountain at a height of $440 \mathrm{~m}$. The city is located between the northern latitudes of 350-52 '/ 37ㅇ-04' and the east longitudes of 35-40 '/ 36-35' and has a significant position within cities with a Turkish-Islamic character (Kara, 2005). Antakya, which has an important value for Jews, Muslims and Christians, has been under the rule of different civilizations in the historical process and this has led to an increase in the diversity of religion and culture there. It is seen that the religious structures constructed very close to each other contribute to the identity of the city by factors such as material, form, size and structure section with their own unique styles.

Gaziantep: Gaziantep is located between $36^{\circ} 28$ 'and 38 $01^{\prime}$ east longitudes and $36^{\circ} 38^{\prime}$ 'and $37^{\circ} 32^{\prime}$ north latitudes. The total surface area of the province is $6745 \mathrm{~km}^{2}$ and it is surrounded by Kahramanmaraş in the north, Adıyaman in the northeast, Kilis and Syria in the south, Hatay in the southwest and Şanlıurfa in the east (TMMOB, 2009).

1/1000 scale Antakya and Gaziantep Protected Areas in the Urban Development Plan was selected as the study area. The location of the urban protected area is given in Figure 1.

Figure 1. Figure 1. Locations of Urban Sites (Taşçıŏlu, 2018)

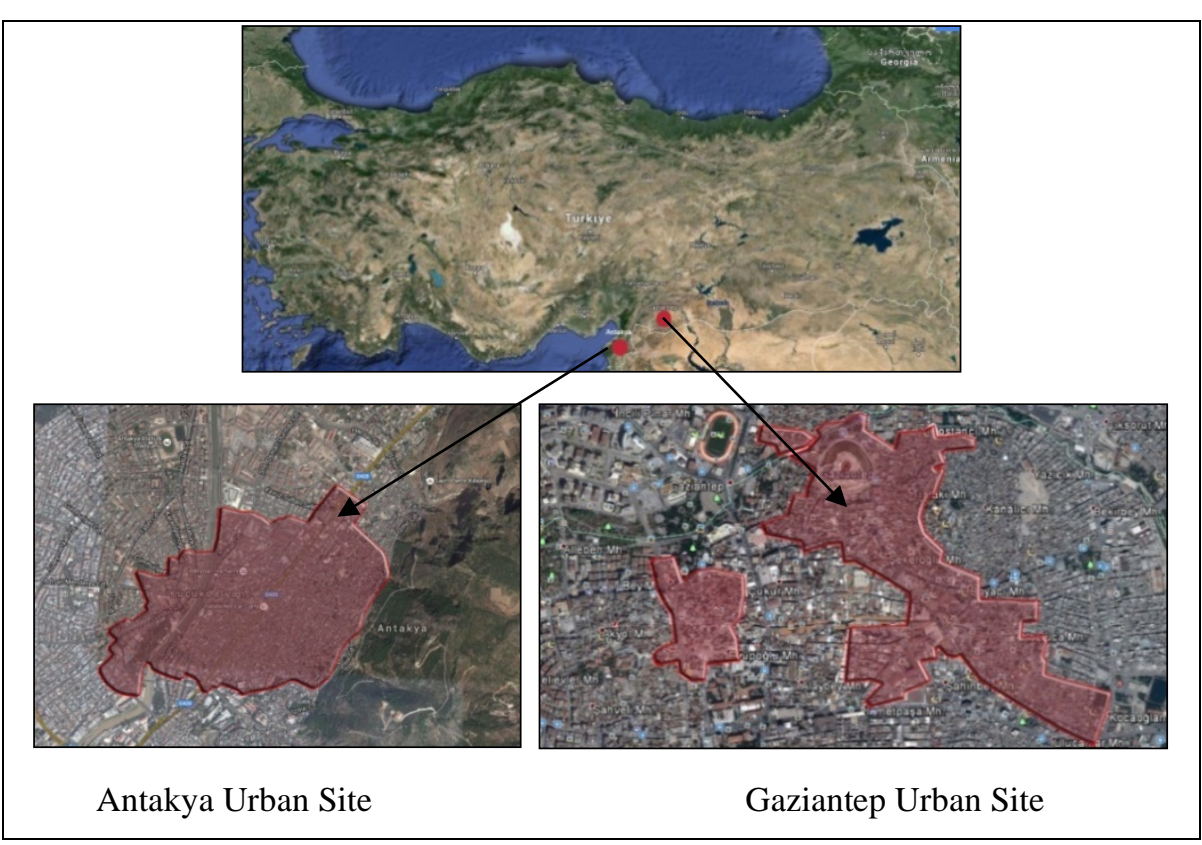

\section{Analytical Framework}

The study utilizes;

Antakya and Gaziantep Master Plans, 1/1000 scale Antioch and Gaziantep Current and Conservation Zoning Plans, Provincial Culture and Tourism inventories and documents obtained from Regional Board 
of Conservation of Cultural and Natural Assets, sketches, plans, maps, photographs, historical information from the local people, old and current photographs taken in the research area, visual examinations and reviews, previous studies on the subject, Autocad 2014, ArcGIS 10.2 software.

Based on (Taşçıoğlu, 2018) method, this study consists of three phases;

1- Traditional fabric analysis,

2- Identifying urban identity elements and historical urban protection criteria,

3- The quantitative assessment of protection levels, weighting, calculation of protection index values and creation of protection index distribution maps.

\section{Traditional fabric analyses}

Analyses were conducted under the titles of Courtyard, Structure, Street and Square for the cities of Antakya and Gaziantep. In line with these analyses, which were conducted based on a total of 22 criteria, the evaluation criteria were graded between 1 and 5 in order to make quantitative evaluation for the determined identity elements.

\section{Identifying urban identity elements and historical urban protection criteria}

In the second stage of the method, urban identity elements and historic city protection criteria were determined. The evaluation criteria were developed based on (Lynch, 1960), (Eckbo, 1969) and (Güremen, 2011). In the light of this information, urban identity elements consisting of 19 main criteria and 61 sub-criteria were determined based on settlement and urban reinforcement scale of the research area. These criteria are described below:

Settlement Scale: Monumental Structures, Examples of Civil Architecture, Buildings with no historical value in terms of compatibility, Street, Courtyard and Square,

Reinforcement Scale: Infrastructure Connected with Reinforcement Elements, Infrastructure Not Connected with Reinforcement Elements and Green Texture,

Evaluation Criteria: Preservation Level, Intervention Level, Original Structure and Material, Renovated Structure and Material, Workmanship, Building Material, Architectural Feature, Floor Height, Facade Layout, Originality Status, New Arrangement, Compliance with Historical Texture, Labor, and Aesthetics. 
A Proposad Method for Evaluating the Conservation of Historical Urban Environments

The charts were scored by the researchers in accordance with the traditional texture analysis chart and graded according to evaluation criteria.

\section{Quantitative Assessment, Protection Index Values and Protection Index Maps}

In the evaluation phase of the study, the findings obtained from urban identity elements evaluation and fabric analysis charts were evaluated quantitatively. In the evaluations, the building structures in the study areas (examples of civil architecture, monumental buildings, buildings without historical value, streets and squares) were evaluated according to the 5-point Likert scale.

As stated in the method, the weighting study was obtained by multiplying the general values of the urban identity elements with the coefficients determined in accordance with expert opinions. Expert opinions landscape architect, architect, expert in urban and regional planning is determined based on feedback from a total of 15 people.

These values are;

\section{Identity Elements}

Historical Building

Historic Street

Historic Courtyard

Historic Square

Non-Historic Building as

Weighting Coefficient
4.88
4.25
3.63
3.75
1.88

Indexing method was applied in order to compare the general values of urban identity elements, For this purpose, it is assumed that the maximum value that can be taken for each property is 100 , and the protection index values are calculated by proportioning each property value to this value.

In the next step, the urban identity elements identified were interpreted in accordance with the protection index values and maps were created by using the Reverse Weighting Method used by Duymuş (2018). In order to create the protection index maps, the values determined in the previous step were transferred to the GIS software and processed on digital aerial photographs. Thus, the urban identity elements determined within the boundaries of the study were transformed into curves and coloured according to the distance to other points. Structure, Courtyard, Street and Square conservation index maps were created separately for the elements identified within the Antakya Urban Protected Area. The value ranges were determined as 0-20\%, 20.01$40 \%, 40.01-60 \%, 60.01-80 \%, 80.01-100 \%$ and expressed in different colours.

Finally, an integrated conservation map was created where all these identity elements were combined, and the identity elements identified within the urban site were evaluated together. It was obtained by 
summing the index values of the selected identity elements within the $100 \times 100$ m area during the creation of the map; transferred to the GIS software, and classified in the highest and lowest ranges and expressed in different colours. The value ranges are proportioned with the assumption that the maximum value is 100 , and the data that would form the basis for the interpretations about the urban protected area were obtained with these maps.

\section{RESULTS AND DISCUSSIONS}

Determination of Urban Identity Elements and Index Values

a)Antakya: 8 buildings and courtyards, 22 streets and connected streets, 1 square were evaluated in Antakya (Figure 2).

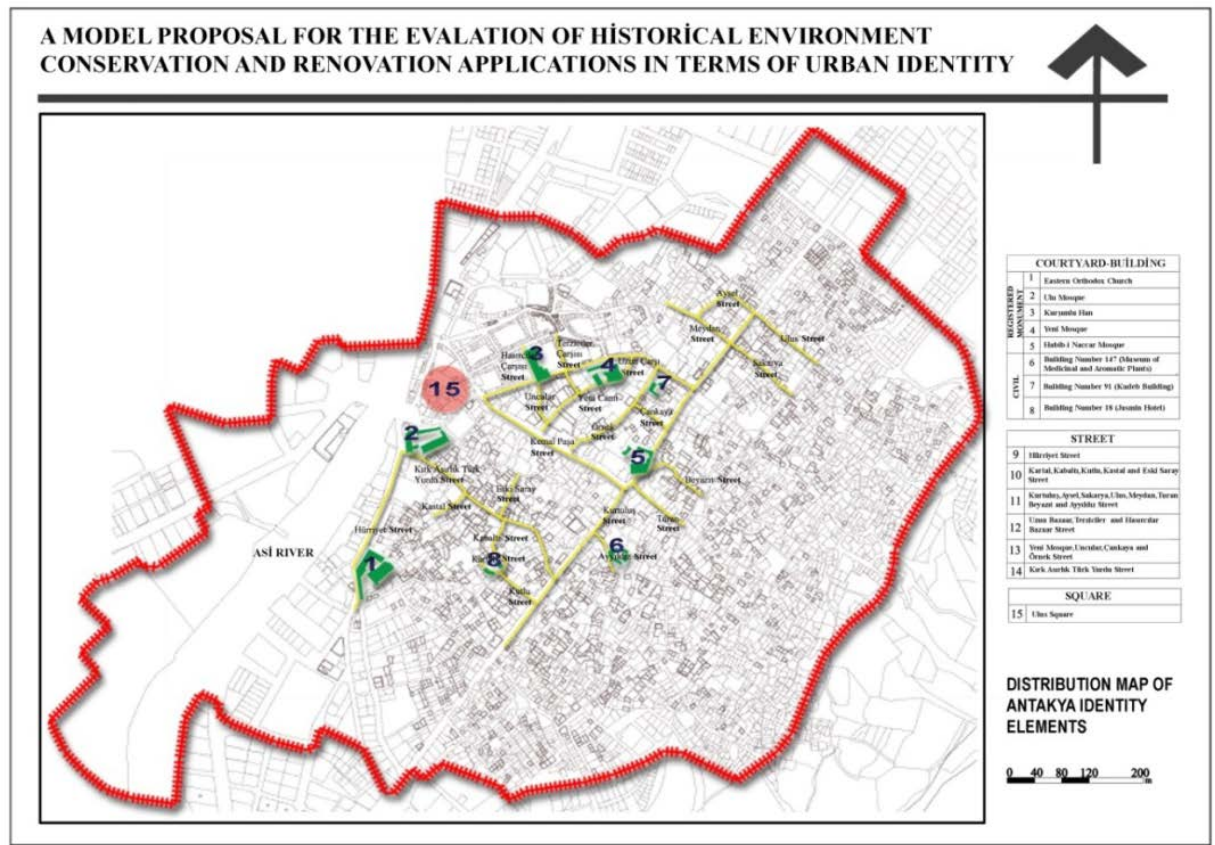

The urban identity elements graded in accordance with traditional texture analysis were scored on visual forms. The index values of the weighted values are expressed in Tables 1, 2, 3 and 4. These values were classified according to certain intervals and evaluated in 5 groups for their suitability.
Figure 2. Distribution of Identity Elements in Antakya Conservation (Taşçığlu, 2018) 
A Proposad Method for Evaluating the Conservation of Historical Urban Environments

Table 1. Conservation Index Values of Antakya City Identity Elements (Courtyard-Structure) (Taşçığlu,2018)

\begin{tabular}{|c|c|c|c|c|c|c|c|c|c|}
\hline \multicolumn{3}{|c|}{ Unit } & \multicolumn{2}{|c|}{$\begin{array}{c}\text { Conservation } \\
\text { Level }\end{array}$} & \multirow{2}{*}{$\begin{array}{c}\begin{array}{c}\text { Intervention } \\
\text { Level }\end{array} \\
76.66\end{array}$} & \multirow{2}{*}{$\begin{array}{c}\begin{array}{c}\text { Original } \\
\text { Structure } \\
\text { and } \\
\text { Materials }\end{array} \\
88 \\
\end{array}$} & \multirow{2}{*}{$\begin{array}{c}\begin{array}{c}\text { Renovated } \\
\text { Building } \\
\text { and } \\
\text { Materials }\end{array} \\
70\end{array}$} & \multirow{2}{*}{$\begin{array}{c}\text { Workmanship } \\
73.33\end{array}$} & \multirow{2}{*}{$\begin{array}{r}\text { General } \\
\text { Feature } \\
80.93\end{array}$} \\
\hline \multirow{8}{*}{ 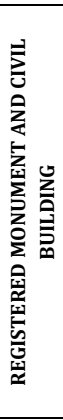 } & \multicolumn{2}{|c|}{$\begin{array}{l}\text { Eastern Orthodox } \\
\text { Church }\end{array}$} & \multicolumn{2}{|c|}{96.66} & & & & & \\
\hline & \multicolumn{2}{|l|}{ Ulu Mosque } & \multicolumn{2}{|c|}{86.66} & 80 & 80 & 60 & 83.33 & 78 \\
\hline & \multicolumn{2}{|l|}{ Kurșunlu Han } & \multicolumn{2}{|c|}{80} & 76 & 86.66 & 70 & 80 & 80.28 \\
\hline & \multicolumn{2}{|l|}{ Yeni Mosque } & \multicolumn{2}{|c|}{90} & 84 & 93.33 & 68 & 76.66 & 82.4 \\
\hline & \multicolumn{2}{|c|}{ Habib-i Naccar Mosque } & \multicolumn{2}{|c|}{93.33} & 73.33 & 100 & 66.66 & 73.33 & 81.33 \\
\hline & \multicolumn{2}{|c|}{$\begin{array}{l}\text { Building Number } 147 \\
\text { (Museum of Medicinal } \\
\text { and Aromatic Plants) }\end{array}$} & \multicolumn{2}{|c|}{88} & 80 & 64 & 75 & 80 & 77.4 \\
\hline & \multicolumn{2}{|c|}{$\begin{array}{l}\text { Building Number } 91 \\
\text { (Kudeb Building) }\end{array}$} & \multicolumn{2}{|c|}{77.14} & 91.42 & 90 & 75 & 80 & 82.71 \\
\hline & \multicolumn{2}{|c|}{$\begin{array}{l}\text { Building Number } 18 \\
\text { (Jasmin Hotel) }\end{array}$} & \multicolumn{2}{|c|}{84} & 73.33 & 90 & 68 & 73.33 & 77.73 \\
\hline \multicolumn{3}{|c|}{ Unit } & \multicolumn{2}{|c|}{$\begin{array}{c}\text { Conservation } \\
\text { Level }\end{array}$} & $\begin{array}{c}\text { Intervention } \\
\text { Level }\end{array}$ & $\begin{array}{l}\text { Original } \\
\text { Structure } \\
\text { and } \\
\text { Materials }\end{array}$ & $\begin{array}{c}\text { Renovated } \\
\text { Building } \\
\text { and } \\
\text { Materials }\end{array}$ & Workmanship & $\begin{array}{l}\text { General } \\
\text { Feature }\end{array}$ \\
\hline \multirow{8}{*}{ 莺 } & \multicolumn{2}{|c|}{$\begin{array}{l}\text { Eastern Orthodox } \\
\text { Church }\end{array}$} & \multicolumn{2}{|c|}{90.1} & 79.8 & 90.61 & 51.48 & 72.08 & 76.81 \\
\hline & \multicolumn{2}{|l|}{ Ulu Mosque } & \multicolumn{2}{|c|}{86.49} & 82.38 & 75.51 & 41.19 & 75.51 & 68.1 \\
\hline & \multicolumn{2}{|l|}{ Kurşunlu Han } & \multicolumn{2}{|c|}{82.38} & 70.02 & $\overline{92.67}$ & 51.48 & 61.78 & 71.67 \\
\hline & \multicolumn{2}{|l|}{ Yeni Mosque } & & & 85.32 & 92.67 & 61.78 & 74.14 & 82.79 \\
\hline & Habib-i Nacca & que & & & 78.94 & 82.38 & 61.78 & 72.08 & 76.88 \\
\hline & $\begin{array}{l}\text { Building Num } \\
\text { (Museum of M } \\
\text { and Aromatic }\end{array}$ & & & & 68.65 & 82.38 & 75.51 & 77.23 & 75.85 \\
\hline & $\begin{array}{l}\text { Building Num } \\
\text { (Kudeb Buildi }\end{array}$ & & & & 82.38 & 89.24 & 82.38 & 77.23 & 84.09 \\
\hline & $\begin{array}{l}\text { Building Num } \\
\text { (Jasmin Hotel }\end{array}$ & & & & 70.61 & 90.61 & 56.63 & 70.61 & 75.54 \\
\hline & $0-20 \%$ & & $-40 \%$ & & $40.01-60 \%$ & & $01-80 \%$ & $80.01-10$ & \\
\hline & Appropriate & & $\begin{array}{l}\text { lly } \\
\text { riate }\end{array}$ & Moc & ately Appropria & Fairly & propriate & Appropr & \\
\hline
\end{tabular}

Table 2. Conservation Index Values of Antakya City Identity Elements (Courtyard-Structure) (Taşçıŏlu,2018)

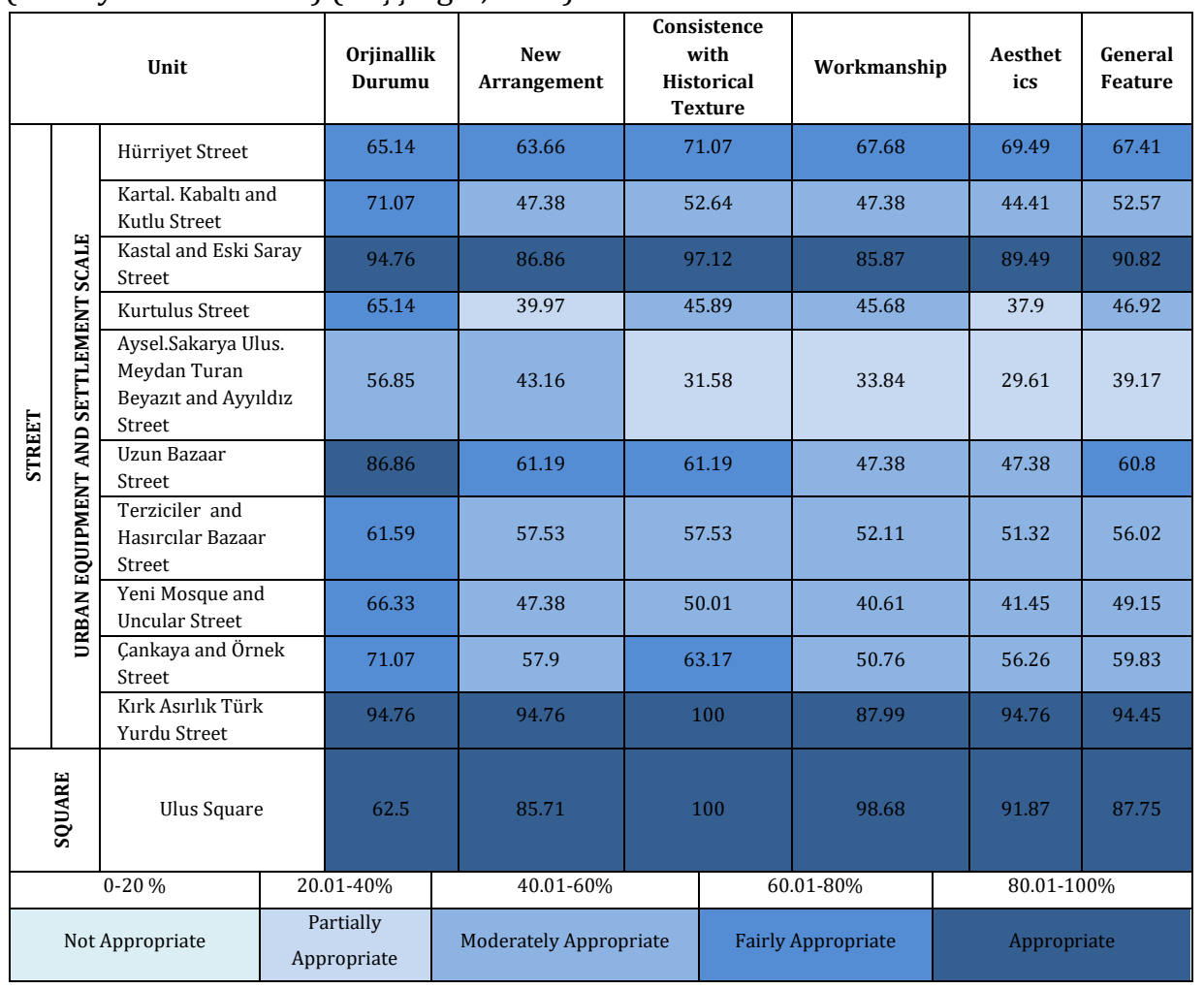


When the Antakya Conservation Index Values in Tables 1 and 2 are interpreted, the following general conclusions can be reached:

$\checkmark$ It was determined that the highest conservation index value belonged to Yeni Mosque (82.4\%), the lowest value belonged to Ulu Mosque (78\%). The highest value among registered civic buildings belonged to KUDEB building (82.71\%) and the lowest value belonged to The Museum of Medicinal and Aromatic Plants (77.4\%). When all the buildings were evaluated as evaluation criteria, the highest criterion belonged to Habib-i Naccar Mosque with original buildings and materials criteria (100\%) and the lowest criterion was renovated buildings and materials which belonged to Ulu Mosque (60\%). In the restoration works, it is observed that material changes and additions that are not compatible with the original texture of the city have damaged the buildings' value. In this sense, the importance of the arrangements reflecting the spatial accumulations can be seen in the statistical values obtained. The lowest value of the original structure and material belonged to Museum of Medicinal and Aromatic Plants (64\%).

$\checkmark$ Among the buildings considered as courtyards, the highest conservation index value was $82.79 \%$ in Yeni Mosque and the lowest value was $68.1 \%$ in Ulu Mosque. The highest value in the courtyards of Civil Buildings was in KUDEB building with $84.09 \%$ while the lowest value was in Jasmin Hotel with $75.54 \%$. When all the courtyards were compared according to the evaluation criteria, the highest conservation value belonged to Yeni Mosque with $100 \%$ while the lowest value was Ulu Mosque with 41.19\%. taking renovated structure and material as criteria. It can be concluded that the additions and material changes in the courtyard affect the structure negatively. This is supported by the fact that the value of renovated building material was low in Kurşunlu Han (51.48\%) and Jasmin Hotel (56.63\%).

$\checkmark$ Of the samples examined under the street title, Kırk Asırlık Türk Yurdu Street had the highest conservation index value with $94.45 \%$ while the lowest score (39.17\%) belonged to Aysel, Sakarya, Ulus, Square, Turan, Beyazıt and Ayyldiz Streets. In terms of street evaluation criteria, the highest compliance with historical texture scores belonged to Kırk Asırlık Türk Yurdu Street (100\%) while the lowest aesthetic criteria belonged to Aysel, Sakarya, Ulus, Meydan, Turan, Beyazit and Ayyldiz Streets (\% 29.61). It can be concluded that Kırk Asırlık Türk Yurdu Street with high values and with its renovated traditional character might serve as an example of the renovation works to be carried out on the streets (Table 4). 
A Proposad Method for Evaluating the Conservation of Historical Urban Environments

$\checkmark$ Ulus Square has a value of $87.75 \%$. The criterion containing the lowest value is originality $(62.5 \%)$.

At the end of the study, the value of all identity elements was taken into consideration and processed on a map and expressed as a result map. When the findings in Figure 3 are examined:

- It is seen that the index values of identity elements vary between 67 and 654. In this context, the highest value is 654 in Uzun Bazaar. This value is followed by $\mathbf{5 7 6}$ index value in Kırk Asırlık Türk Yurdu Street. The lowest value is 67 in the surroundings of Hürriyet Street.

- The index values are at the highest in Uzun Bazaar area, gradually decrease from Hurriyet Street to Aysel, Ulus, Meydan, Turan, Beyazit Streets and reach the lowest value there.

Figure 3. Antakya City Identity Elements Integrated Conservation (Taşçıŏlu, 2018)
Map

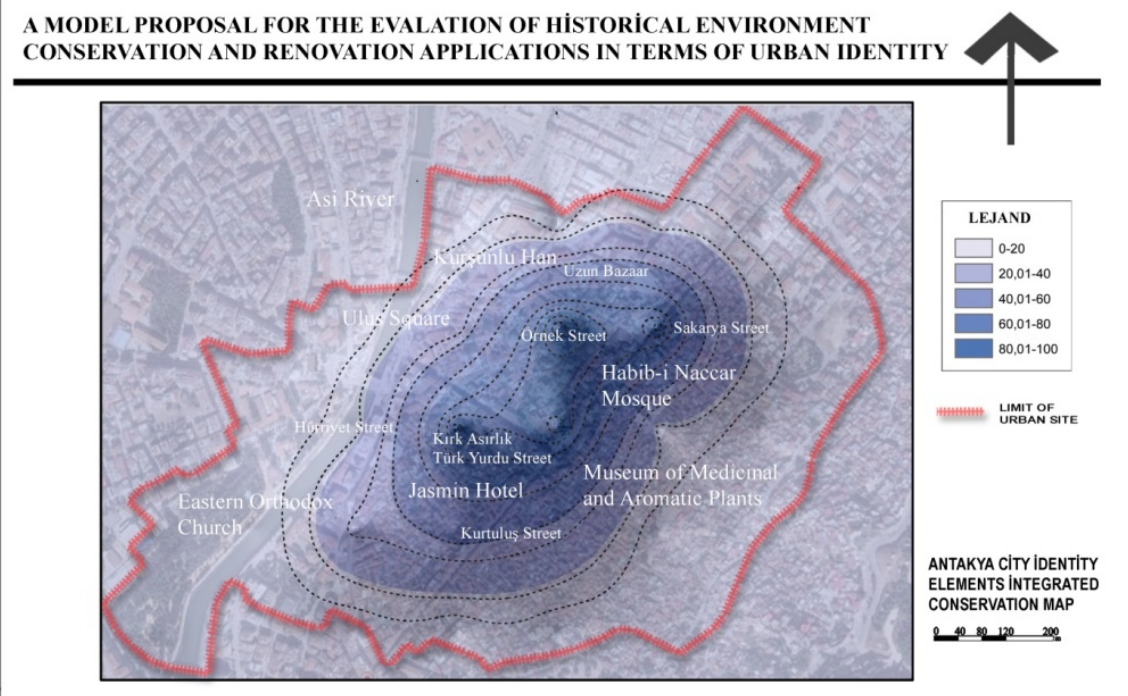

b) Gaziantep: As part of Gaziantep identity elements, 13 buildings ( 9 monumental, 4 civic buildings), 13 courtyards, 5 streets, 52 connected streets and 1 square were evaluated in Gaziantep (Figure 4). 


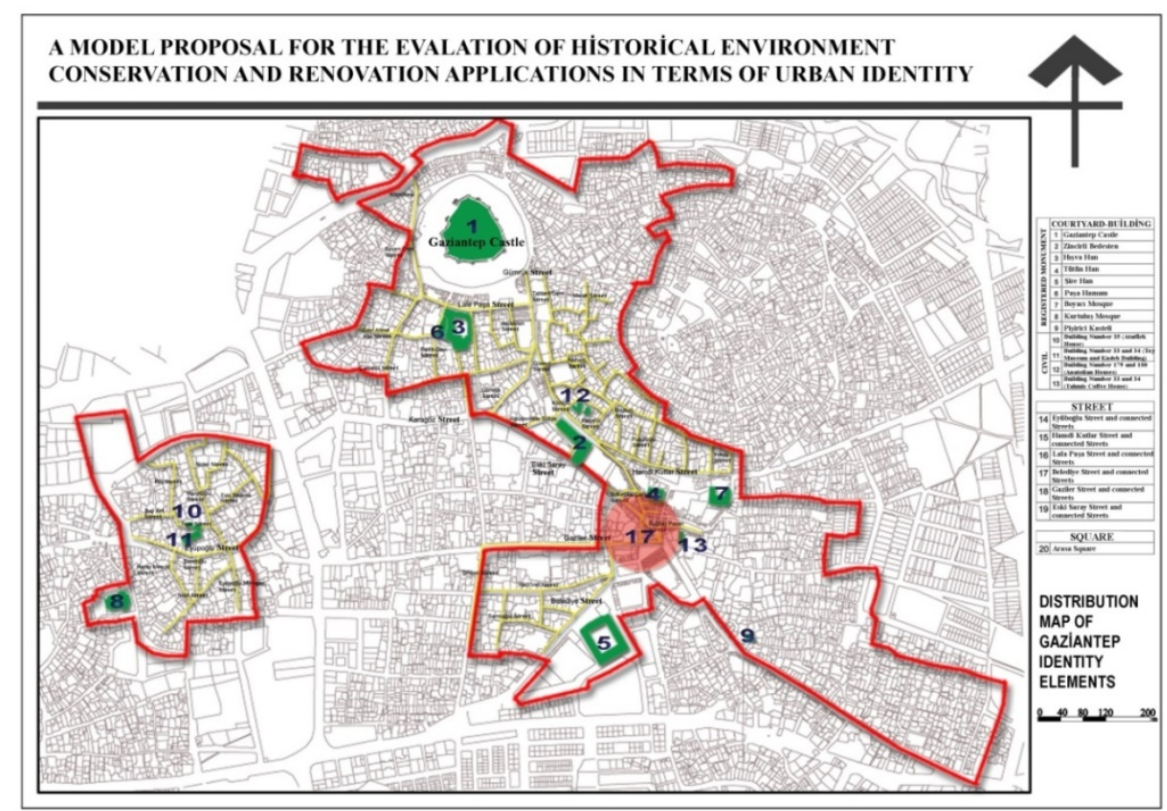

Figure 4. Distribution of Identity Elements in Gaziantep Conservation Plan (Taşçığlu,2018)

Table 3. Conservation Index Values of Gaziantep City Identity Elements (Courtyard-Structure) (Taşçığlu,2018)

\begin{tabular}{|c|c|c|c|c|c|c|c|}
\hline & Unit & $\begin{array}{c}\text { Conservation } \\
\text { Level }\end{array}$ & $\begin{array}{c}\text { Intervention } \\
\text { Level }\end{array}$ & $\begin{array}{c}\text { Original } \\
\text { Structure and } \\
\text { Materials }\end{array}$ & $\begin{array}{c}\text { Renovated } \\
\text { Building } \\
\text { and } \\
\text { Materials }\end{array}$ & Workmanship & $\begin{array}{l}\text { General } \\
\text { Feature }\end{array}$ \\
\hline \multirow{13}{*}{ 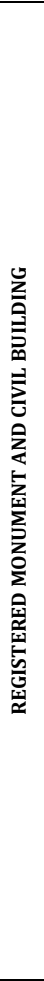 } & $\begin{array}{l}\text { Gaziantep } \\
\text { Castle }\end{array}$ & 78.57 & 78.57 & 82.21 & 56.58 & 69.56 & 73.09 \\
\hline & $\begin{array}{l}\text { Zincirli } \\
\text { Bedesten }\end{array}$ & 90.34 & 77.29 & 87.83 & 59.02 & 80.8 & 81 \\
\hline & Hışva Han & 93.35 & 87.83 & 91.34 & 73.77 & 84.31 & 90.04 \\
\hline & Tütün Han & 87.33 & 77.29 & 77.29 & 67.45 & 77.29 & 81.60 \\
\hline & Şire Han & 75.28 & 59.72 & 89.58 & 56.21 & 77.29 & 74.23 \\
\hline & Paşa Hamam & 90.34 & 80.8 & 80.8 & 84.31 & 84.31 & 84.11 \\
\hline & $\begin{array}{l}\text { Boyacl } \\
\text { Mosque }\end{array}$ & 87.33 & 87.83 & 94.85 & 63.23 & 84.31 & 84.16 \\
\hline & $\begin{array}{l}\text { Kurtulus } \\
\text { Mosque }\end{array}$ & 91.34 & 88.53 & 94.85 & 84.31 & 84.31 & 88.67 \\
\hline & $\begin{array}{l}\text { Pişirici } \\
\text { Kasteli }\end{array}$ & 86.33 & 84.23 & 100 & 66.68 & 72.53 & 81.96 \\
\hline & $\begin{array}{l}\text { Building } \\
\text { Number } 35 \\
\text { (Atatürk } \\
\text { House) } \\
\end{array}$ & 86.95 & 84.31 & 84.31 & 73.77 & 79.04 & 81.68 \\
\hline & $\begin{array}{l}\text { Building } \\
\text { Number } 33 \\
\text { and } 34 \\
\text { (Toy Museum } \\
\text { and Kudeb } \\
\text { Building) } \\
\end{array}$ & 87.83 & 80.8 & 84.31 & 63.23 & 80.8 & 79.40 \\
\hline & $\begin{array}{l}\text { Building } \\
\text { Number } 179 \\
\text { and } 180 \\
\text { (Anatolian } \\
\text { Houses) }\end{array}$ & 91.34 & 80.8 & 70.26 & 80.1 & 84.31 & 81.36 \\
\hline & $\begin{array}{l}\text { Building } \\
\text { Number } 33 \\
\text { and } 34 \\
\text { (Tahmis } \\
\text { Coffee House) }\end{array}$ & 84.31 & 73.77 & 84.31 & 56.21 & 79.04 & 75.53 \\
\hline \multirow{6}{*}{ 总 } & Unit & $\begin{array}{c}\text { Conservation } \\
\text { Level }\end{array}$ & $\begin{array}{c}\text { Intervention } \\
\text { Level }\end{array}$ & $\begin{array}{c}\text { Original } \\
\text { Structure and } \\
\text { Materials }\end{array}$ & $\begin{array}{c}\text { Renovated } \\
\text { Building } \\
\text { and } \\
\text { Materials }\end{array}$ & Workmanship & $\begin{array}{l}\text { General } \\
\text { Feature }\end{array}$ \\
\hline & $\begin{array}{l}\text { Gaziantep } \\
\text { Castle } \\
\end{array}$ & - & - & - & - & - & - \\
\hline & $\begin{array}{l}\text { Zincirli } \\
\text { Bedesten }\end{array}$ & - & - & - & - & - & - \\
\hline & Hışva Han & 86.66 & 86.66 & 100 & 80 & 80 & 86.66 \\
\hline & Tütün Han & 85 & 85 & 90 & 40 & 60 & 72 \\
\hline & Şire Han & 54.28 & 51.42 & 80 & 66.66 & 66.66 & 63.8 \\
\hline
\end{tabular}


A Proposad Method for Evaluating the Conservation of Historical Urban Environments

\begin{tabular}{|c|c|c|c|c|c|c|}
\hline Paşa Hamam & - & - & - & - & - & - \\
\hline $\begin{array}{l}\text { Boyacı } \\
\text { Mosque }\end{array}$ & 84 & 75 & 100 & 40 & 65 & 72.8 \\
\hline $\begin{array}{l}\text { Kurtuluş } \\
\text { Mosque }\end{array}$ & 80 & 80 & 50 & 60 & 60 & 66 \\
\hline $\begin{array}{l}\text { Pișirici } \\
\text { Kasteli }\end{array}$ & - & - & - & - & - & - \\
\hline $\begin{array}{l}\text { Building } \\
\text { Number } 35 \\
\text { (Atatürk } \\
\text { House } \\
\text { Inneryard) }\end{array}$ & 85 & 75 & 86.66 & 40 & 75 & 72.33 \\
\hline $\begin{array}{l}\text { Building } \\
\text { Number } 33 \\
\text { and } 34 \text { (Toy } \\
\text { Museum and } \\
\text { Kudeb } \\
\text { Building } \\
\text { Courtyards) }\end{array}$ & 76 & 60 & 70 & 53.33 & 72 & 66.26 \\
\hline $\begin{array}{l}\text { Building } \\
\text { Number } 33 \\
\text { and } 34 \\
\text { (Anatolian } \\
\text { Houses) } \\
\text { Courtyard }\end{array}$ & 92 & 84 & 95 & 70 & 76 & 83.4 \\
\hline $\begin{array}{l}\text { Building } \\
\text { Number } 328 \\
\text { (Tahmis } \\
\text { Coffee House) } \\
\text { Courtyard }\end{array}$ & - & - & - & - & - & - \\
\hline
\end{tabular}

Table 4. Conservation Index Values of Gaziantep City Identity Elements (Courtyard-Square) (Taşçığlu,2018)

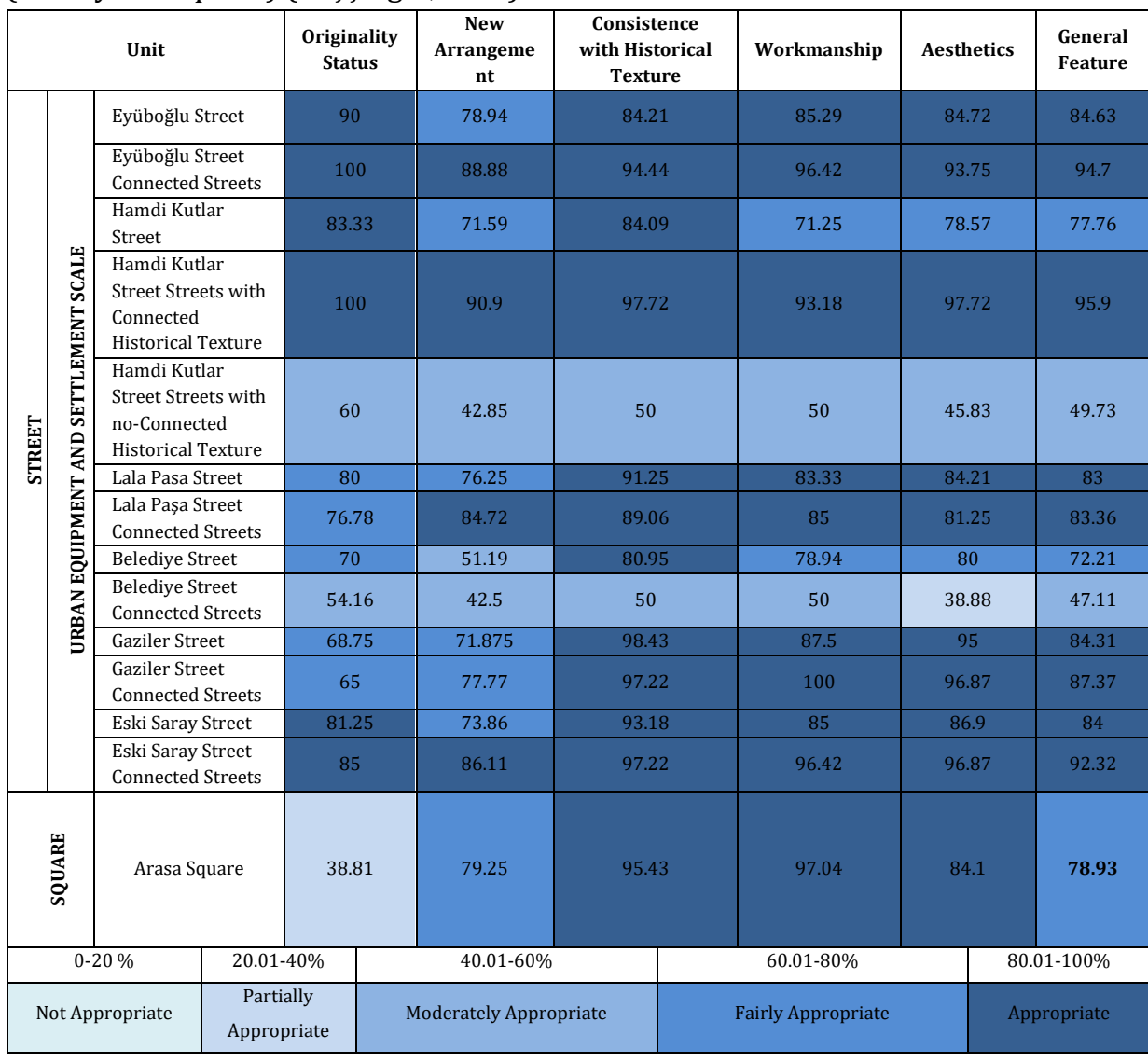

When the Gaziantep Conservation Index Values are examined, the following main conclusions can be obtained: 
$\checkmark$ Among the registered monumental buildings, Hisva Han has 90.04\% conservation index value while Gaziantep Castle has the lowest value $(73.09 \%)$. The highest value for the registered civil structure belongs to Anatolian Houses (81.36\%) while the lowest one belongs to Tahmis Coffee House (75.53\%). When all the buildings were evaluated as the evaluation criteria, the highest criterion is original structure and material which belong to Pişirici Kastel (100\%) while the lowest criterion is renovated structure and material which belong to Tahmis Coffee House and Şire Han (56.21\%).

$\checkmark$ In the restoration works, it is observed that material changes and additions that are not compatible with the original texture of the city have damaged the buildings' value. In this sense, the importance of the arrangements reflecting the spatial accumulations can be seen in the statistical values obtained. The highest value in terms of original structure and material was determined in Pişirici Kastel (100\%) and the lowest value in Anatolian Houses (70.26\%). It can be considered that commercial use causes changes in the structure.

$\checkmark$ Among the courtyards, Hisva Han has the highest index value with $86.66 \%$, and Şire Han has the lowest value with $63.8 \%$. When all the courtyards are compared according to evaluation criteria, it was observed that the highest criterion is original building and martial in Hisva Han ve Boyacı Mosque (100\%), and the lowest criterion is renovated building and material in Tütün Han, Boyacı Mosque and Atatürk Memorial House (40\%).

$\checkmark \quad$ It can be concluded that the additions and material changes in the courtyard affect the structure negatively. This can be clearly seen in the courtyard of the Kurtuluş Mosque (50\%), where the original structure and the material are at the lowest.

$\checkmark$ Among the streets, Hamdi Kutlar Street has preserved its historical value $(95.9 \%)$ while the streets that are connected to the same street cannot (49.73\%). Considering that it has a value of $77.76 \%$ as the main street, it can be interpreted as a reflection of the positive and negative effects of protected and unprotected streets connected to the street. The streets with the lowest value are the ones connected to Belediye Street (47.11\%) (Table 4).

$\checkmark$ Arasa Square, which is considered to be a square, is observed to have $78.93 \%$ value. Its originality value was found to be $38.1 \%$.

At the end of the study, the value of all identity elements was taken into consideration and processed on a map and expressed as a result map. When the findings in Figure 5 are examined:

- It is seen that the index values of identity elements vary between $\mathbf{8 0}$ and 1118. In this context, the highest value is 1118 in the surroundings of Anatolian Houses. This value is followed by Tütün 
A Proposad Method for Evaluating the Conservation of Historical Urban Environments

Hanı with 1034 index value. The lowest value is determined around Pişirici Kastel with 80.

- After a gradual decrease to zero value starting from Anatolian Houses where the index values are at the highest, it reaches to an index value of $\mathbf{6 8 3}$ around Kurtuluş Mosque in Bey neighbourhood. This situation supports the fact that the connection between these two areas should be stronger in the city where there are two separate urban protected areas.

Figure 5. Gaziantep City Identity Elements Integrated Conservation (Taşçıoğlu, 2018)

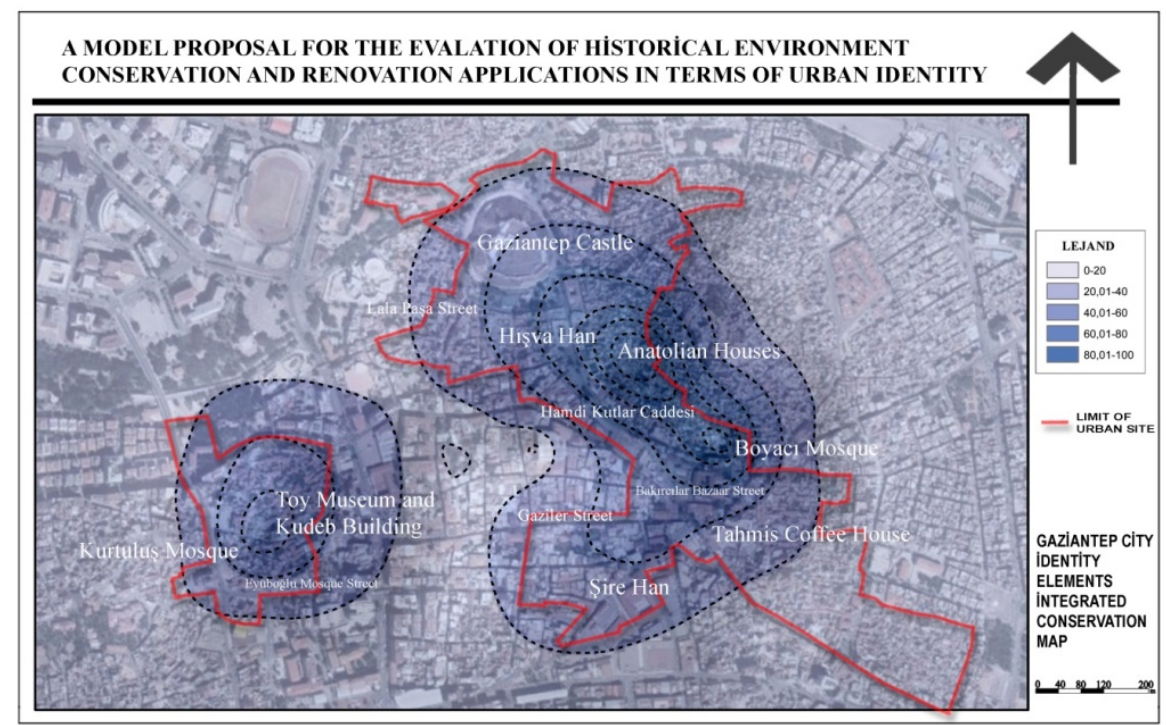

This study aims to evaluate the conservation and renovation works carried out in the urban protected areas in Gaziantep and Antakya based on the urban identity elements and to determine their conservation status. In the light of the findings, it has been determined that the value of the historical texture can be preserved by adopting the traditional fabric and faithful conservation works, but the additions and material changes have negative effects. Sales units and metal stairs placed in the Kurşunlu Han courtyard in Antakya, the cover system in Hisva Han courtyard and the profile additions to Şire Han in Gaziantep are some of them.

All these findings emphasize the necessity of preventing the lack of protection or loss which can occur in conservation works. (Özer, 1998), (Yaldız \& Asatekin, 2016), (Kale, 2011), (Rodwell, 2014), (Yuen, 2005), (Radoslav et al, 2013), and (Wang, 2011) support that conservation works ins historical sites should be integrated and include sustainable practices. In addition, (Çelik, 2004) stated in his study that the targeted protection could not be achieved in conservation works conducted in Beypazarl. He stated that the restoration of the historical buildings' facade was done, but it was not considered as a whole with their gardens. As reasons for the failure of the targeted protection, he shows the deficiencies in law and regulations, lack of supervision during the implementation process, lack of social awareness, insufficient resources 
and political pressures. Research that tries to determine the problems related to protection states that errors should be minimized in the implementation and detailed analysis should be done for the purpose. Considering that many buildings are used for commercial and social reasons today, it has a great contribution to the historical texture as it provides its inhabitants both with tourism and social life opportunities. In this sense, as (Çelik \& Yazgan, 2007) stated, the people fit for keeping the historical environment alive are those who have an emotional connection with them and have a mutual history.

\section{CONCLUSION}

This study aims to evaluate the conservation and renovation works carried out in the urban protected areas in Gaziantep and Antakya based on the urban identity elements and to determine their conservation status. In the light of the findings, it has been determined that the value of the historical texture can be preserved by adopting the traditional fabric and faithful conservation works, but the additions and material changes have negative effects. Sales units and metal stairs placed in the Kurşunlu Han courtyard in Antakya, the cover system in Hisva Han courtyard and the profile additions to Şire Han in Gaziantep are some of them.

When the studies carried out in Gaziantep and Antakya urban sites are examined, it can be said that the material choices that are not related to the existing materials have negative consequences for Courtyard, Building, Street and Square. Additions to structures and courtyards lead to visually negative effects as well as to deterioration. Although this situation is thought to be related to the functional changes in the structures, it is seen that examples from foreign countries do not implement such practices. It can be thought that this difference is due to the balance of using protection in a holistic approach and an approach that does not go beyond the traditional character. Moreover, in the examples related to the conservation and usage, it is seen that historical environments are not isolated from new settlements, but they still have the feature of being a centre and integrity for that city.

The maps created as a result of the study conducted in Gaziantep and Antakya are important in terms of reflecting their conservation status. In this context, in terms of preserving the identity of the city, it shows the positive results that can be experienced depending on the preservation of existing historical or cultural values, as well as the effect of non-preserved examples.

\section{ACKNOWLEDGMENTS}

I would like to thank my instructors and colleagues for their valuable contributions to this research. This study was produced from the doctoral study "A Model Proposal for the Evaluation of Historical Environmental Conservation and Renovation in terms of Urban Identity" 
A Proposad Method for Evaluating the Conservation of Historical Urban Environments

an completed in the Department of Landscape Architecture, Institute of Science and Technology, Cukurova University. The study was supported by the Scientific Research Projects Coordination Unit of Çukurova University with the project number 2016-7583 and we thank you for this support.

\section{CONFLICT OF INTEREST}

There is not any conflict of interest

\section{FINANCIAL DISCLOSURE}

The authors declared that this study has received no financial support.

\section{ETHICS COMMITTEE APPROVAL}

Ethics committee approval was not required for this article.

\section{LEGAL PUBLIC/PRIVATE PERMISSIONS}

In this research, the necessary permissions were obtained from the relevant participants (individuals, institutions, and organizations) during the survey and in-depth interviews.

\section{REFERENCES}

Cohen, N. (1999). Urban Conservation. The Mit Press,Cambridge.

Çelik, D. (2004). Kentsel Peyzaj Tasarımı Kapsamında Tarihi Cevre Yenileme Çalışmalarının Peyzaj Mimarlığı Açısından Araştırılması: Beypazarı Örneği, Ankara Üniversitesi, Fen Bilimleri Enstitüsü, Doktora Tezi

Çelik, D., \& Yazgan, M.E. (2007). Kentsel Peyzaj Tasarımı Kapsamında Tarihi Çevre Korumaya Yönelik Yasa ve Yönetmeliklerin İrdelenmesi, ZKÜ Bartın Orman Fakültesi Dergisi, 9(11):1-10. http://dergipark.ulakbim.gov.tr/barofd/article/view/5000057065/500 0054276 Erişim tarihi:17.06.2018

Dhingra, M., Singh, M. K., \& Chattopadhyay, S.(2016). Macro Level Characterization of Historic Urban Landscape: Case Study of Alwar Walled City. City, Culture and Society. 1-15.

Duymuş, H. (2018). Cevresel Algılamanın Kentsel Peyzaj Tasarımı Yönünden Değerlendirilmesinde Bir Model Önerisi: Tarsus Kenti Örneği, Çukurova Üniversitesi, Fen Bilimleri Enstitüsü, Doktora Tezi, Adana.

Eckbo, G.( 1969). The Landscape We See. Mc Graw Hill Book Campany, USA.

Erdönmez, M. E. \& Akı, A. (2005). Açık kamusal kent mekanlarının toplum ilişkilerindeki etkileri. YTÜ Mimarlık Fakültesi e-Dergisi, 1 (1): 67-87.

Esendemir, Ș. (2015). Şehrin Kökeni, Muhafazakar ve Modernist Halleri. Şehir ve Medeniyet. (9):32-37. 
Güremen, L. (2011). Kent Kimliği Ve Estetiği Yönüyle Kentsel Donatı Elemanlarının Amasya Kenti Özelinde Araştırılması. e-Journal of New World Sciences Academy Social Sciences, 6, (2), 254-291.

Hergül, C.Ö. \& Sayın, G. (2017). Küreselleşme Ekseninde Kent Kimliği Olgusunun İrdelenmesi. 6. Peyzaj Mimarlığı Kongresi. I. Cilt, 429-437, Antalya.

Kale, B. (2011).Tarihsel Kent Peyzajlarının Korunması, Hamamönü Örneği, Yüksek Lisans Tezi, Ankara Üniversitesi, Fen Bilimleri Enstitüsü, Ankara.

Kara, A. (2005). 19. Yüzyılda Bir Osmanlı Şehri ANTAKYA. IQ Kültür Sanat Yayıncllik, $288 \mathrm{~s}$.

Lynch, K., (1960). The Image of the City, The Mit Press,194 s, Cambridge.

Özer, M. N. (1998). Planlı ve Tasarlı Yaşam Alanlarının Kent Kimliği Üzerindeki Etkileri: Antalya Örneği. Yüksek Lisans Tezi, Gazi Üniversitesi, Fen Bilimleri Enstitüsü, Ankara.

Radoslav,R., Branea, A.M., \& Gaman, S.M. (2013). Rehabilitation Through a Holistic Revitalization Strategy of Historical City Centres Timisoara, Romania. Journal of Cultural Haritage (Elsevier) 14S(2013)e1-e6

Rodwell, D. (2014). Sustannability and the Holistic Approach to the Conservation of Historic Cities. Journal Of Architecture Conservation, 9:1, 58-73.

Taşçıoğlu, S. (2018) .Kent Kimliği Açısından Tarihi Çevre Koruma Çalışmalarının Değerlendirilmesinde Bir Model Önerisi, Çukurova Üniversitesi, Fen Bilimleri Enstitüsü, Doktora Tezi, Adana.

Tiesdell, S., Oc, T \& Heath,T. (1996). Revitalizing Historic Urban Quarters, Architectural Press,234p.

TMMOB, (2009). Tarihi Çevrede Koruma: Uygulamalar, Yaklaşımlar, TMMOB Mimarlar Odası Ankara Şubesi, Ankara.http://www.mimarlarodasiankara.org/dosya/dosya14-1.pdf, Erişim tarihi:03.03.2016.

Velioğlu, A., Araz, A., \& Tavşan, C.(1993) Koruma Olgusu İçinde Mimari Tasarım Süreci: Kavramsal, Kuramsal, Felsefi Yaklaşımlar, 1.Kentsel Koruma ve Yenileme-Uygulamalar Kolokyumu, Bildiriler Kitabı, s.208216, 7-8 Nisan 1993, MSÜ, İstanbul

Yaldız,E. \& Asatekin, G.N. (2016). Anitsal Yapıların Yeniden Kullanımında İşlevsel Adaptasyonun, Mekânsal Analiz Yolu ile Değerlendirilmesi: Kayseri Sahabiye Medresesi, Türk-İslam Medeniyeti Akademik Araştırmalar Dergisi, 21:89-112.

Yuen, B. (2005). Searching For Places İdentity in Singapore.Habitat International, 29(2), 197-214.

Wang, J. (2011). Problems and Solutions İn The Protection of Historical Urban Areas. Frontiers of Architectural Research(Elsevier).1:40-43.

\section{Resume}

Saliha Taşçıoğlu is an Assistant Professor in the Program of Landscape and Ornamental Plants, Kilis 7 Aralik University. After he completed his master's 
A Proposad Method for Evaluating the Conservation of Historical Urban Environments

degree at Mustafa Kemal Üniversitesi University in 2013, received his Ph.D. in Landscape Architecture from Cukurova University in 2018. The area of interest focuses on conservation historical environment, urban design and urban identity. Berrin Sirel is working as an Assistant Professor in the Department of Landscape Architecture at Cukurova University. She received his Ph.D. in Landscape Architecture from Cukurova University in 1995. His main research subjects are landscape design, landscape construction and playgrounds. 